УДК 347.122

DOI https: / / doi.org/10.32837 / yuv.v0i4.1978

\title{
Д. Спєсівцев,
}

кандидат юридичних наук,

старший викладач кафедри цивільно-правових дисциплін

Східноєвропейського національного університету імені Лесі Українки

\section{ЕФЕКТИВНІСТЬ СПОСОБУ СУДОВОГО ЗАХИСТУ СУБ'ЄКТИВНИХ ЦИВІЛЬНИХ ПРАВ НА НЕРУХОМЕ МАЙНО}

Постановка проблеми. Незважаючи на те, що термін «ефективність» у контексті способів судового захисту суб'єктивних цивільних прав наразі вживається в положеннях чинного цивільного процесуального (ч. 2 ст. 5 Цивільного процесуального кодексу України [1, ст. 5] (далі - ЦПК України)) й господарського процесуального законодавства (ч. 2 ст. 5 Господарського процесуального кодексу України [2, ст. 5] (далі - ГПК України)), він використовується для комплексного позначання здатності відповідного способу захисту забезпечити досягнення відповідної мети, зокрема у формі припинення порушення суб'єктивних цивільних прав і відновлення вже порушених суб'єктивних цивільних прав. У зв'язку із цим явище, позначуване термінологічним словосполученням «ефективний спосіб захисту», має матеріальний цивільноправовий характер і належить до цивілістичної проблематики цивільноправового захисту суб'єктивних цивільних прав.

Однією зі сфер, для якої проблема ефективності способів захисту має найбільшу актуальність, виступає цивільний оборот нерухомості. Ускладненість механізмів виникнення, переходу й припинення речових прав на нерухоме майно такими елементами, як прийняття об’єкта в експлуатацію, державна реєстрація прав на нього, нотаріальне посвідчення правочинів щодо нерухомості тощо зумовлюють необхідність ретельного підходу до обрання способу захисту відповідних суб'єктивних цивільних прав на нерухоме майно. Адже вбачається, що в певних обставинах правової реальності ефективністю може наділятись один спосіб захисту, в той час, як в інших обставинах - другий. У зв'язку із цим з'ясування сутності ефективності способу захисту суб'єктивних цивільних прав на нерухоме майно $€$ однією 3 умов визначення порядку застосування відповідного захисного інструментарію в умовах практики правореалізації та правозастосування.

Аналіз останніх досліджень i публікацій. Проблема ефективності способу судового захисту суб'єктивних цивільних прав ставала предметом розгляду таких вчених, як С.С. Алексєєв, I.В. Андронов, I.В. Венедіктова, І.В. Жилінкова, О.С. Іоффе, А.В. Коструба, О.О. Красавчиков, О.О. Кот, Н.С. Кузнєцова, P.A. Майданик, В.В. Надьон, О.О. Отраднова, М.О. Рожкова, Я.M. Романюк, I.В. Спасибо-Фатєєва, Л.Г. Талан, Р.О. Халфіна, Г.Г. Харченко, С.М. Хорунжий, Я.М. Шевченко, Р.Б. Шишка, О.Я. Явор, В.Л. Яроцький та інші.

Постановка завдання. Мета статті полягає у визначенні сутності ефективності способу судового захисту суб'єктивних цивільних прав на нерухоме майно як умови, що окреслює порядок його застосування 
у випадках практики правореалізації та правозастосування.

Основний матеріал дослідження. Термінологічне словосполучення «ефективний спосіб захисту» знайшло формальне закріплення в положеннях ЦПК України й ГПК України з викладенням цих нормативно-правових актів у новій редакції від 03 жовтня 2017 року. Однак важливість позначуваного ним явища демонструється його втіленням в один із визначальних принципів інституту цивільноправового захисту суб'єктивних цивільних прав.

Аналіз відповідних нормативних положень, судової практики й цивілістичних розробок показує, що ефективність способу захисту $€$ однією 3 його властивостей, яка може мати різні якісні характеристики. У зв'язку із цим проблему необхідно розглядати структурно, що сприятиме формуванню повного розуміння його правової природи.

1. Належність способу захисту суб'єктивних цивільних прав на нерухоме майно.

Термін «належність» не вживається для позначення властивостей способу захисту в положеннях ані чинного цивільного, ані чинного цивільного процесуального чи господарського процесуального законодавства України. Проте його епізодичне вживання можна зустріти в цивілістичній літературі [3, с. $26 ; 4$, с. 55], а також в окремих судових рішеннях, наприклад, у постанові Касаційного господарського суду в складі Верховного Суду від 23 червня 2020 року у справі № 905/633/19 [5].

У Великому тлумачному словнику сучасної української мови значення слова «ефективний» описується, зокрема, як «такий, що приводить до потрібних результатів, наслідків, дає найбільший ефект. Який викликає ефект» [6, с. 358]. Своєю чергою «належний» $€$, зокрема, «таким, який має зв'язок із ким-, чим-небудь, стосунок до когось, чогось. Який потрібний, необхідний, відповідний» [6, с. 721].

У зв'язку із цим слово «ефективний» позначає здатність спричиняти певний результат або найбільший ефект, у той час, як слово «належний» позначає, зокрема, відношення до чогось, відповідність чомусь. Тому належним способом захисту суб'єктивних цивільних прав на нерухоме майно є такий спосіб, що відповідає відповідному праву, стосується нього, а якщо точніше - відповідає порушенню такого права, адже захист протиставляється саме порушенню суб'єктивного цивільного права. Ефективним же способом захисту виступає такий, що здатен, зокрема, припинити порушення, відновити порушене право, забезпечити відшкодування завданої шкоди тощо.

У наукових дослідженнях, у рамках яких розглядається, зокрема, ефективність способу захисту суб'єктивних цивільних прав, можна угледіти спроби вчених схарактеризувати відповідну властивість способу захисту, що належить саме до належності. Наприклад, Т.О. Родоман вказує на те, що вибір способу захисту залежить від характеру правопорушення та особливостей правовідносин між сторонами 3 метою ефективного їх поновлення [7, с. 69]. I хоча вчений прямо не вказує про те, що відповідний спосіб захисту повинен бути належним, це слідує з описаної ситуаціі. Перефразовуючи відповідний підхід, ми отримаємо тезу, відповідно до якої спосіб захисту суб'єктивних цивільних прав на нерухоме майно повинен відповідати характеру правопорушення та особливостям правовідносин між його сторонами, тобто мати належний характер.

У своїй постанові від 18 грудня 2019 року у справі № 522/1029/18 Велика Палата Верховного Суду, зокрема, вказала, що судом першої інстанції було вірно встановлено, що 3 огляду на те, що позивач стверджує про перебування 3 товари-

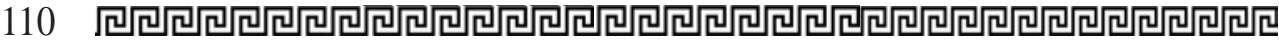


ством з обмеженою відповідальністю в зобов'язальних правовідносинах, то права позивача повинні захищатися за допомогою відповідних норм інституту зобов'язального права (п. 120) [8, п. 120]. Суд не вказує на те, що позивачем обрано неналежний або неефективний спосіб захисту. Проте, якщо виходити з того, що речово-правові способи не можуть бути використані для захисту зобов'язальних суб'єктивних цивільних прав, вимоги в тому числі, в обороті нерухомості, а ця проблема вимагає окремої уваги, то в зазначеній постанові Суду йдеться саме про обрання позивачем неналежних способів захисту.

Необхідно погодитись із тим, що ефективним може бути лише належний спосіб захисту суб'єктивних цивільних прав на нерухоме майно. Проте, зважаючи на ту обставину, що в положеннях чинного цивільного, а також цивільного процесуального й господарського процесуального законодавства України не вживається термін «належний», для практики правореалізації та правозастосування належність способу захисту необхідно розглядати як елемент ефективності. У такому разі під час використання позивачем неналежного за своєю природою способу захисту суд може відмовити в його застосуванні 3 підстав його неефективності, розуміючи водночас неналежність відповідного способу.

2. Власне ефективність способу захисту суб'єктивних цивільних прав на нерухоме майно.

У світлі викладеного вище належність способу захисту суб'єктивних цивільних прав на нерухоме майно можна розглядати в широкому й у вузькому розуміннях. У широкому розумінні належність способу захисту розглядається як його відповідність характеру порушення. У такому розумінні спосіб захисту мислиться окремо від конкретної правової ситуаціі. У зв'язку із цим належними способами судового захисту речових прав на нерухоме майно взагалі є віндикаційний позов, негаторний позов, позов про визнання права власності Й інші.

У вузькому розумінні належність способу захисту визначається його здатністю досягти визначеної мети в конкретній правовій ситуаціі та $€$ ефективністю у власному значенні цього слова. Зокрема, як зазначає А.M. Мірошниченко, під час розв'язання питання про порушення провадження по будь-якій справі суду слід з'ясовувати, чи приведе застосування способу захисту, обраного позивачем, до захисту його порушеного чи оскарженого права [3, с. 30]. $\mathrm{У}$ такому випадку йдеться про конкретну справу й про ефективність (належність) способу в конкретних умовах. Адже, якщо нерухома річ перебуває у фактичному володінні власника, то він не може використати такий спосіб захисту свого права власності на неї, як віндикаційний позов. Незважаючи на те, що цей спосіб захисту права власності належний взагалі, в конкретній ситуації він має неналежний характер, адже позбавлений здатності припинити порушення чи відновити порушене право власника або ж не допустити порушення в разі реальної загрозй його вчинення.

3 цього приводу в наукових дослідженнях також відзначається, що ефективний спосіб захисту забезпечує реальний захист прав [4, с. 144].

Відповідне положення знайшло відбиття і в практиці Європейського суду з прав людини. Зокрема, у справі Теренс і Маурін Дорани проти Ірландіï Суд вказав на те, що спосіб захисту повинен бути ефективним як у контексті положень законодавства, так і в практиці, а ефективність способу захисту означає в тому числі те, що він повинен бути адекватним і доступним (п. п. 55-62) [9, п. 55-62].

Також Касаційний господарський суд в складі Верховного Суду в постанові від 23 червня 2020 року у справі № 905/633/19 зазначив про те, що 
належний спосіб захисту, виходячи із застосування спеціальної норми права, повинен забезпечити ефективне використання цієї норми в іi практичному застосуванні - гарантувати особі спосіб відновлення порушеного права або можливість отримання нею відповідного відшкодування (абз. 2 п. 62) [5, п. 62].

У світлі зазначеного, власне ефективним способом захисту суб'єктивних цивільних прав на нерухоме майно $€$ такий належний спосіб, що здатен у коректній практичній ситуації досягти визначеної мети, зокрема у формі припинення порушення, відновлення порушених прав на нерухоме майно, а за неможливості цього - відшкодування завданої шкоди.

3. Рівень ефективності способу захисту суб'єктивних цивільних прав на нерухоме майно.

Положення чинного цивільного, а також цивільного процесуального й господарського процесуального законодавства України не встановлюють критерії, за допомогою яких можна визначити, який із наявних належних та ефективних способів захисту суб'єктивних цивільних прав на нерухоме майно $є$ ефективнішим, а який менш ефективний.

Ця проблема набуває актуального значення в умовах практики правореалізації та правозастосування, коли закон визначає можливість захисту суб'єктивного цивільного права декільком способами або одним із них. Зокрема, в окремих випадках закон прямо встановлює право особи обрати один із декількох пропонованих способів захисту суб'єктивних цивільних прав. Наприклад, ч. 1 ст. 858 Цивільного кодексу України надає право замовнику у випадку відступів підрядником від договору підряду, які погіршили роботу, за своїм вибором вимагати безоплатного усунення недоліків у роботі в розумний строк; пропорційного зменшення ціни роботи або відшкодування своїх витрат на усунення недоліків, якщо право замовника усувати їх встановлено договором [10, ст. 858].

Водночас невизнання права власності особи на нерухоме майно, що супроводжується ґï позбавленням володіння відповідною нерухомою річчю в окремих випадках виступає умовою одночасного застосування таких способів захисту, як визнання права власності на нерухоме майно i його вимога із чужого незаконного володіння.

Юридичні механізми виникнення, переходу й припинення речових прав на нерухоме майно мають складніший характер у порівнянні 3 аналогічними механізмами стосовно прав на рухомі речі. Адже для них характерні, зокрема, такі елементи, як прийняття новозбудованого об’єкта нерухомого майна в експлуатацію, державна реєстрація речових прав на нерухоме майно, зокрема, права власності й похідних речових прав тощо. У зв'язку із цим в конкретних умовах практики правореалізації та правозастосування може виникнути ситуація, коли особі необхідно обрати такий спосіб або способи захисту, що здатні забезпечити досягнення найповнішого результату.

Як зазначає А.О. Штанько, ефективність способу захисту оцінюється за фактично досягнутими потрібними результатами відповідно до поставленої мети цивільноправового захисту майнових цивільних прав та інтересів у межах, забезпечуваних призначенням і властивостями цього способу захисту [11, с. 208-209]. У цьому сенсі під «ефективним» слід розуміти такий спосіб, що приводить до потрібних результатів, наслідків, дає найбільший ефект [12, с. 46]. Іншими словами, за можливості застосування одного 3 декількох або одночасно декількох способів захисту суб' $є$ тивних цивільних прав на нерухоме майно ефективним способом або комбінацією способів вважається той спосіб (комбінація способів), що здатен забезпечити досягнення найбільш 
комплексного результату. За наявності можливості застосування способу захисту, що здатен забезпечити повне відновлення порушеного суб'єктивного цивільного права, застосуванню підлягає саме такий спосіб, а не той, що може забезпечити лише часткове його відновлення.

Як приклад можна навести висновок Касаційного господарського суду в складі Верховного Суду, викладений у постанові від 10 грудня 2019 року у справі № 910/979/19, в якому суд вказав на те, що позивач просить суд визнати за ним право на користування нежитловим приміщенням.

Однак така вимога позивача фактично спрямована на встановлення судом юридичного факту, а задоволення такої вимоги не приведе до реального поновлення прав позивача й не усуне перешкоди в користуванні майном, оскільки зазначена вимога не може бути виконана в примусовому порядку [13, п. 34-37]. Проблема в тому, що в цій справі відповідач чинить перешкоди позивачу в здійсненні ним господарської діяльності на орендованих площах торговельно-розважального центру, зокрема шляхом встановлення охорони й недопущення працівників до торгових точок. У зв'язку із цим, хоча визнання права користування і $€$ належним способом його захисту, що визначений положеннями чинного цивільного законодавства України (п. 1 ч. 2 ст. 16 ЦК України) [10, ст. 16], проте в цій конкретній ситуації його використання не здатне забезпечити найповніший ефект. Дійсно, з описаних дій відповідача можна зробити висновок, що він чинить перешкоди позивачу в користуванні відповідним майном, у тому числі й у зв'язку з тим, що не визнає відповідного права позивача. Проте, якщо в цій ситуації буде використано лише такий спосіб захисту права користування нежитловим приміщенням, як визнання такого права, то існує ризик того, що відповідач не припинить здійснення перешкод позивачу в здійсненні такого права. Тобто захист буде неповним і створюватиме передумови для використання додаткових способів. У зв'язку із цим використаний позивачем спосіб $€$ «не досить ефективним» або "менш ефективним» способом захисту, ніж наявні альтернативи, які можуть бути використані в цій ситуаціі. Тому в контексті усталеної термінології використаний спосіб захисту неефективний.

Висновки й перспективи подальших досліджень. Підбиваючи підсумок під викладеним вище, необхідно зазначити, що ефективність способу захисту суб'єктивних цивільних прав на нерухоме майно $€$ комплексним поняттям, яке стосується властивості відповідного способу захисту та його якісної характеристики.

Зокрема, як така властивість виступає здатність способу захисту забезпечити досягнення відповідного результату у формі припинення порушення, відновлення порушених прав на нерухоме майно, а за неможливості цього - відшкодування завданої шкоди. Іншими словами, це властивість належності способу захисту.

Водночас ефективність у такому сенсі (належність) може розумітись у широкому й у вузькому значеннях. У широкому розумінні належність способу захисту розглядається як його відповідність характеру порушення. У такому сенсі ефективними способами захисту права власності на об'єкти нерухомого майна є, зокрема, віндикаційний, негаторний позови, позов про визнання права власності й інші, які взагалі можуть бути використані для захисту права власності. Своєю чергою у вузькому розумінні ефективним (належним) способом захисту права власності на об'єкт нерухомого майна є такий спосіб, який може досягти визначеного результату в умовах конкретної правової обставини, в тому числі взагалі може бути використаний у відповідних умовах (власне ефективний спосіб). 
Водночас характеристика ефективних способів захисту суб'єктивних цивільних прав на нерухоме майно може мати різну якість в конкретних умовах, в яких вони були застосованими. У зв'язку із чим у випадку можливості застосування лише одного з декількох або одночасно декількох способів захисту суб'єктивних цивільних прав на нерухоме майно ефективним способом або комбінацією способів вважається той спосіб (комбінація способів), що здатен забезпечити досягнення найбільш комплексного результату.

Статmя містить результати наукового дослідження ефективності як критерію застосування способу судового захисту суб'єктивних цивільних прав на нерухоме майно. Встановлюеться, що в умовах дії положень чинного цивільного, а також ицвільного процесуального й господарського процесуального законодавства України ефективність розглядається як визначальний критерій застосування способу захисту в конкретній правовій ситуації. Водночас положення чинного законодавства України не розкривають чітко зміст критерію, що актуалізуе необхідність його наукового осмислення, в тому числі в контексті способів захисту суб'єктивних изивільних прав на нерухоме майно.

У процесі дослідження автор звертається до сучасних лексикографічних джерел, які розкривають сутність ефективності як характеристики певного явища, а також до правових позицій вищих судових інстаниій із приводу відповідної властивості способу захисту суб'єктивних цивільних прав.

Встановлюється, що ефективнicms способу захисту суб'ективних циивільних прав на нерухоме майно $є$ комплексним поняттям, яке охоплюе три компоненти:

1) належність способу захисту в изілому. У такому розумінні належність способу захисту розглядається як його відповідність характеру порушення. Ефективними в такому сенсі способами захисту права власності на об’єкти нерухомого майна є, зокрема, віндикаційний, негаторний позови, позов про визнання права власності й інші, які взагалі можуть бути використані для захисту права власності;

2) власне ефективність способу захисту, яка позначае здатність способу захисту досягти визначеної мети, зокрема не допустити порушення, припинити порушення, відновити порушене право або забезпечити відикодування завданої шкоди в конкретній практичній cumуації;

3) здатність відповідного способу захисту досягти найкомплекснішого результату (ефекту) в конкретній правовій ситуації.

В умовах, коли для захисту суб'єктивних ичивільних прав на нерухоме майно може бути використаний один із декількох способів захисту або одночасно декілька способів захисту, ефективним способом або комбінацією способів вважається той спосіб (комбінація способів), що здатен забезпечити досягнення найкомплекснішого результату.

Ключові слова: захист, спосіб захисту, охорона, нерухоме майно, ефективність.

\section{Spiesivtsev D. The efficiency of judicial way of protection of subjective civil rights on immovable property}

The article contains the results of scientific research of the efficiency as a criterion for enforcement the way of judicial protection of subjective civil rights on immovable property. It is defined that in context of current civil as well as civil procedural and commercial procedural legislative provisions of Ukraine the efficiency is 
considered as determinative criteria for enforcement appropriate way of protection in concrete juridical situation. At the same time legislative provisions of current civil law of Ukraine do not reveal clearly the nature of mentioned criterion that is the factor that actualizes the necessity of it scientific comprehension particularly in context of ways of protection of subjective civil rights on immovable property.

During the research the author turns to the modern lexicographical sources that reveal the nature of the efficiency as characteristics of certain phenomenon as well as to the juridical positions of highest courts dedicated to appropriate features of the ways of protection of subjective civil rights on immovable property.

It is defined that the efficiency of the way of protection of subjective civil rights on immovable property is a complex concept that covers tree main components:

1) proper character of the way of protection on the whole. According to this meaning the proper character means the conformity of the protective way to the kind of rights violation. The proper way of protection of property rights on immovable property in this context is vindication, negatory lawsuit, lawsuit on recognition of right of property etc. that can be used in appropriate situation for protection of property right;

2) actually the efficiency of protective way that denotes the ability of protective way to achieve the goal, particularly to prevent the violation, terminate it or to provide compensation for the caused damage in concrete practical situation;

$3)$ the ability of appropriate protective way to achieve the most complete result (effect) in concrete juridical situation.

In circumstances when only one among several juridical ways or several ways at one time can be used in order to protect subjective civil rights the effective way or combination of ways is the way (combination of ways) that can provide the most complete juridical result.

Key words: protection, protective way, safeguard, immovable property, efficiency.

\section{Література}

1. Цивільний проиесуальний кодекс України : Закон України від 18 березня 2004 р. № 1618-IV / Верховна Рада України. Відомості Верховної Ради України. 2004. № № 40-41. Ст. 492 (зі змінами).

2. Господарський процесуальний кодекс України : Закон України від 06 листопада 1991 р. № 1798-XII / Верховна Рада України. Відомості Верховної Ради України. 1992. № 6. Ст. 56 (зі змінами).

3. Мірошниченко А.м. Обрання належного способу захисту прав на земельні ділянки. Адвокат. 2011. № 1 (124). С. 26-31.

4. Петруня В.В. Поняття та система способів захисту прав суб'єктів господарювання : дис. ... канд. юрид. наук : 12.00.04. Oдеса, 2019. 221 c.

5. Постанова Касаційного господарського суду в складі Верховного Суду від 23 червня 2020 р., судова справа № 905/633/19 / Єдиний державний реєcmp судових рішень. URL: http: / / reyestr. court.gov.ua/Review/90176799 (Jama звернення: 23.07.2020).

6. Великий тлумачний словник сучасної української мови / уклад. і голов. ред. В.T. Бусел. 3 дод. і допов. Київ, Ірпінь : Перун, 2005. 1728 с.

7. Родоман T.О. До питання способів захисту иивільних прав та інтересів у контексті положень $\mathrm{cm} .16$ Цивільного кодексу України. Судова апеляція. 2015. № 4 (41). C. 65-70.

8. Постанова Великої Палати Верховного Судувід18грудня 2019 р.,судовасправа № $522 / 1029 / 18$ / Єәиний державний реєcтр судових рішень. URL: http: / / reyestr. court.gov.ua/Review/87144996 (Jama звернення: 23.07.2020).

9. Judgment of European Court of Human Rights of 31.10.2003 in Case of Terence and Maureen Doran v. Ireland (Application No. 50389/99). URL: https: / / hudoc.echr.coe.int/ fre\#\{\%22it 


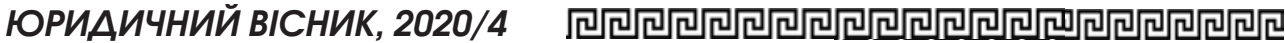

emid\%22:[\%22001-61277\%22]\} (access date: 21.07 .2020$)$

10. Цивільний кодекс України : Закон України від 16 січня 2003 р. № 435-IV / Верховна Рада України. Відомості Верховної Ради України. 2003. №oo 40-44. Ст. 356 (зі змінами).

11. Штанько А.О. Ефективність визнання права як способу захисту майнових иивільних прав та інтересів. Наук. часопис Наи. акад. прокуратури України. 2014. № 4. C. 200-211.
12. Хоменко М.М. Ефективність способів захисту иивільних прав та інтересів у практиці Європейського суду. Юрид. Україна. 2016. № 5-6. С. 45-53.

13.Постанова Касаиійного господарського суду в складі Верховного Суду від 10 грудня 2019 р. судова справа № 910/979/19 / Єдиний державний реєстр судових рішень. URL: http: / / reyestr.court.gov.ua/ Reviеw/86332845 (дата звернення: 23.07.2020). 